\title{
МУЗЫКА
}

\author{
UDC 782.6
}

\section{Giuseppe Sarti and the topos of the tragic in Russian music}

\author{
B. Brover-Lubovsky \\ Jerusalem Academy of Music and Dance, \\ Campus Givat-Ram, Jerusalem, 9190401, Israel
}

For citation: Brover-Lubovsky, Bella. "Giuseppe Sarti and the topos of the tragic in Russian music”. Vestnik of Saint Petersburg University. Arts 9, no. 1 (2019): 4-29. https://doi.org/10.21638/ spbu15.2019.101

Praising Glinka's A Life for the Tzar as an inauguration of Russian music, Vladimir Odoevskii emphasized that its composer succeeded in elevating the figure of a simple peasant to the realm of tragedy. Odoevskii's claim thus embodied the plea for the manifestation of tragedy based on a nationally-driven socially and culturally significant idea, conveyed through a sublime mood. Adopting this domain was indeed a long journey for music in Russia. The present essay traces forerunners and emerging elements of tragedy and its musical implementation back to the last decade of the eighteenth and the beginning of the nineteenth centuries, with an emphasis on Giuseppe Sarti's (1729-1802) impact on the adoption of the tragic and the sublime in Russian music. A survey of Sarti's stage works for the 1780-90s reveals his preferred pattern of conveying a sublime atmosphere of classicistic tragedy through unmeasured text and declamation whether notated or not - located in the cathartic points of the drama, in conjunction with unison chorus and illustrative elements in the orchestra. Sarti's contribution to the marriage of European neo-classicism with local trends and the domestication of tragedy in Russian music is demonstrated through a survey of declamation in recitatives and melodrama styles in works by Evstignei Fomin, Stepan Davydov, Stepan Degtiarev, and Osip Kozlovskii.

Keywords: Eighteenth-century music, music and dramatic theater in Russia, Giuseppe Sarti, Evstignei Fomin, Stepan Davydov, Osip Kozlovskii, tragedy, melodrama, recitative.

Praising Glinka's Zhizn' za Tsaria as an inauguration of Russian music, Vladimir Odoevskii emphasized that its composer succeeded in elevating the figure of a simple peasant and the tunes of plain folk to the realm of tragedy [1, p.126]. Odoevskii's claim thus emphasized the plea for basing the manifestation of tragedy on a nationally-driven,

* This article is part of the research project "Cosmopolitan Composer in (pre)-Revolutionary Europe" funded by Einstein Stiftung Berlin.

(c) Санкт-Петербургский государственный университет, 2019 
socially and culturally significant idea, conveyed through a sublime mood. Adopting this domain was indeed a long journey for music in Russia. The present essay traces the forerunners and emerging elements of tragedy and its musical implementation back to the last decade of the eighteenth and the beginning of the nineteenth century, with an emphasis on Giuseppe Sarti's impact on the adoption of the tragic and the sublime in Russian music.

During his long sojourn in the Russian Empire (1784-1801), Sarti was active as a multifaceted composer, ambitious music director, and illustrious teacher, incorporating current European trends in local ambience. Prior his arrival, and even during his stay in Russia, Sarti's 35 dramme per musica, seven dramme giocose, nine azioni teatrali and pastorali (not including Singspielen in Danish, compiled during his service in Copenhagen) had been successfully performed on various European stages. His previous positions at the Milan Duomo and earlier at the Venetian Ospedale enabled him to gain expertise and esteem in composing solemn choral compositions for the Roman, Ambrosian, and Aquileian rites [2-5]. Sarti’s last works composed prior his departure from his homeland, Giulio Sabino (Venice: S. Benedetto, 1781) and Idalide (Milan: La Scala, 1783), and especially the new operas written for Catherine II's court, Armida e Rinaldo and Castore e Polluce (St. Petersburg: Hermitage, 1786), impressed with their ethical rigor and refined nobility. These and additional works reinforced Sarti's reputation as a champion of the classical movement that powerfully entered European culture in the wake of Johann Joachim Winckelmann's seminal discoveries about ancient arts, Jacques Louis David and Anton Raphael Mengs' paintings, and operas by Christoph Willibald Gluck, Tommaso Traetta, and Antonio Sacchini [6-11; 12, p.329-36]. These works, along with Sarti's late dramatic compositions, impacted the marriage of European classicism with local trends and the domestication of tragedy in Russian music.

One of these works was Alessandro e Timoteo, which premiered on 6 April, 1782, in Parma, Teatro Ducale [I; II; 13-15]. The splendor of this performance - its dazzling vocal virtuosity, orchestral brilliance and outstanding timbral imaginativeness, gorgeous scenery and choreography, and most of all, its moral rigour - highly impressed noble attendees, among them Grandduke Paul Petrovich and his wife Maria Fedorovna, who in fact initiated Sarti's invitation to Russia [14, p. 68; 16, p. 159]. Alessandro e Timoteo is written on a pseudo-Hellenistic source: its librettist Carlo castone della Torre di Rezzonico adopted John Dryden's ode Alexander's Feast: Or, The Power of Music (1697) to suit the conditions of a festa teatrale. In accordance with the traits of this subgenre, Sarti's masterpiece has a one-act structure divided into a dozen scenes. Its subject - the manipulation of a monarch through music - is enacted through a progression of episodes, in which the bard Timoteo arouses various emotions in Alexander the Great. Timoteo sings of Alessandro's mythical descent from Giove, evoking an awareness of his own boldness and audacity. Later he praises the pleasures of wine, encouraging Alessandro to drink, then switches to the sad death of the defeated Persian king Darius, instilling in Alessandro pity for his vanished enemy, and then proceeds with a longing for love. Eventually, Timoteo's song inculcates in Alessandro feelings of anger and vengeance, leading him to burn down the palace in Persepolis.

Musical and literary representation of boldness and the pleasures of wine, love, and revenge lean on a robust operatic tradition that was deployed via vocal numbers - arias, ensembles, choruses - and dances. For mercy, the most complex emotional statement, Sarti assembles an arduous moral combat between Timoteo and the emperor in Scenes 
VII-VIII, the centerpiece of the opera. These form a huge through-composed scene that depicts the moral debate between Alessandro and his bard, during which Timoteo leads his patron through several emotional phases. One of the characteristics of the festa teatrale is the protagonist's license to remain on the scene after singing an aria, unlike in dramma per musica, where the character, after finishing the aria di sortita, must leave. Here, recitativo stromento becomes the main vehicle of the debate, emphasizing its pivotal conceptual, psychological, and dramatic points, and building a coherent discourse. Apart from long sections in various recitative styles, Timoteo's argument is summarized in lavish vocal pieces, such as his cavatina "Pietoso lagrime" (Sc. VII), aria "Nel seno il cor", and rondeau "Bella Dea", contrasting with Alessandro's multi-tempo aria "Odi, grand'Ombra" and a large Coro di Persiani, "Là di Stige su l'orrido lito" (all in Sc. VIII).

Unmeasured verses evoke the flexible combination of various types of declamation: Sarti assigns a traditional secco to Alessandro and his fiancée Barsene, while Timoteo promotes his argument via extensive soliloquies styled as an accompanied recitative, where notated speech alternates with orchestral interjections, or when the declamation and orchestral music overlap. Although in his dramme per musica of the 1770-80s Sarti radically increased the function of recitative, this scene truly astonishes with its length (about 1,000 measures of the score) and its elevated emotional content.

The debate opens with a brief dialogue styled as an accompanied recitative, "Che mediti, Alessandro?" (mm. 1-33 of Sc. VII), in which Timoteo's short phrases alternate with Alessandro's repliques. Here, the declamation of both protagonists is barely supported by instruments, alternating with brief orchestral interjections. In "Son vendicate assai Grecia ed Atene" (mm. 13-18) Timoteo's argument is accompanied by arpeggiated pizzicato figures (imitating his lyre) on E-flat minor chords by winds. Further, his speech turns direction, perceptively mirroring the text: falling down on "Ma del tuo pianto", ascending with metric accents on "generoso Guerrier", and abruptly falling by an octave on "traditor Dario ebbe morte" (see ex. 1).

In Timoteo's cavatina "Pietose lagrime", which encloses this dialogue, his voice is personified by solo English horn; violins and violas play an E-flat major tonic arpeggio in threefold divisi, as an imitation of a lyre, ${ }^{1}$ and a pizzicato of viola solo and cellos con sordini, and this accompaniment pattern reiterates within recitatives. In Scene VIII, after the chorus, Timoteo proceeds with a long somber accompanied recitative (18 lines of versi sciolti, 93 measures). The bard convinces Alessandro that Dario no longer reigns and thus is worthy of his tears. On "Dalle molte piaghe Spiccia a rivoli il sangue" the accompaniment pattern of the cavatina returns, depicting the bard's declamation with the arpeggiated chords of his lyre. (Sarti returns to this device his dramma per musica Andromeda (St. Petersburg: Hermitage, 10 November 1798) [XIV-XVI].

Then follows his excited aria di bravura, "Nel seno il cor mi palpita", after which Timoteo keeps his powerful rhetoric in another accompanied recitative (on 21 lines). During his musing on the briefness and uncertainty of life, "Ma se tanto è la vita incerta e breve", the violins restate brief phrases from the aria, creating an illusion of a cohesive debate. Rhetoric, tempo, tonality, and orchestral accompaniment change abruptly, ranging from grief and sorrow to exclamations of rage. Eventually, Alessandro acknowledges the bard's victory in this battle of eloquence in the secco recitative "Timoteo, hai vinto".

1 The remark "Lorchestra imita il suono d'una cetera pizzicata" in the libretto [I, p. 14] elucidates this intention. I am grateful to Andrea Chegai for pointing out this fact. 

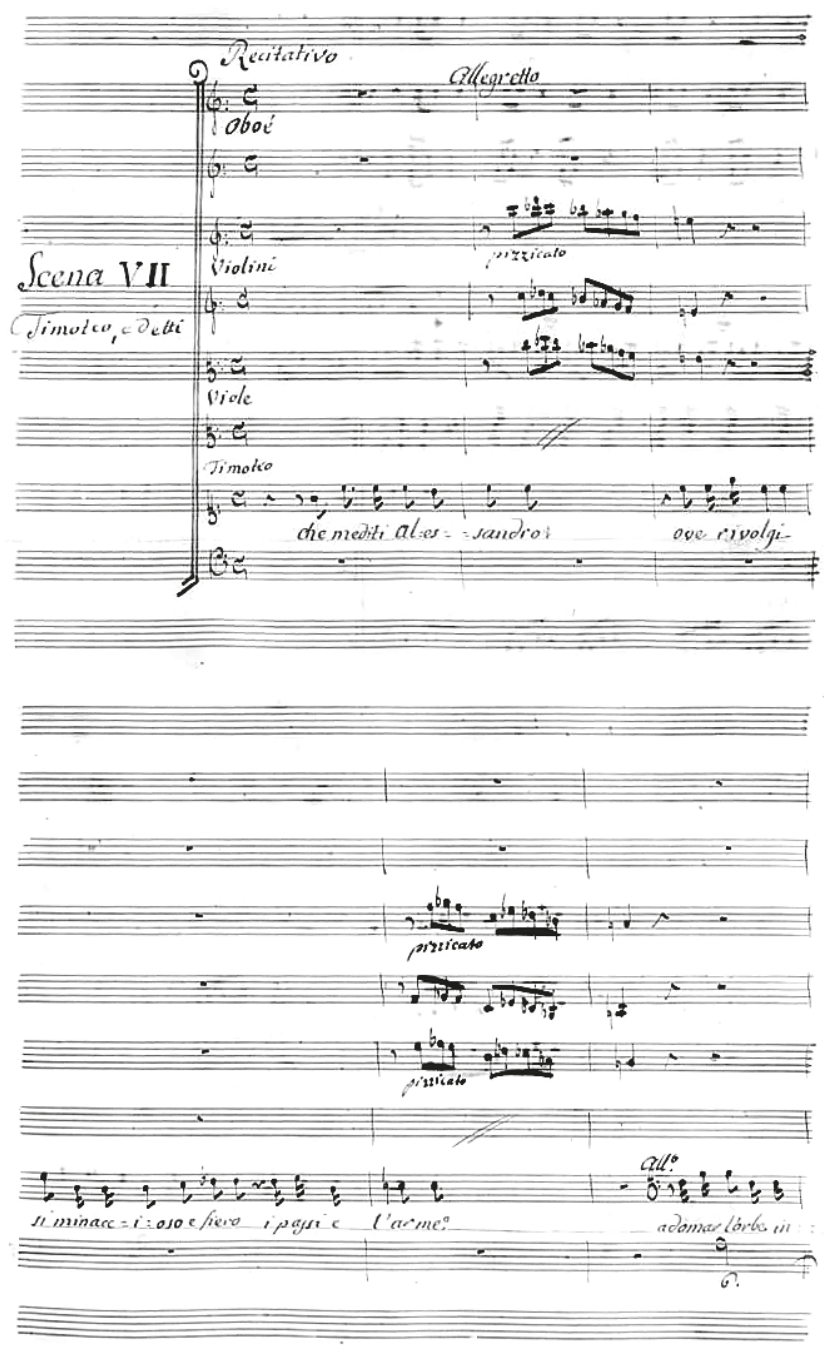

Example 1: Giuseppe Sarti, Alessandro e Timoteo, Scene VII.

Reaching his goal, Timoteo now succeeds in turning Alexander to yearning for desire and pleasure: here the recurring motives of oboe alternate with virtually unaccompanied speech, "Quanto è dolce, Alessandro." Timoteo's graceful rondeau "Bella dea" closes this grandiose display of emotional manipulation.

The dramatic intensity and textual-musical complexity of the recitative scenes were one of Sarti's main achievements as a dramatic composer. These scenes usually increase the dramatic tension and lead to climactic point, such as the tumultuous meeting of Giulio Sabino with Epponina and Tito, "Venite o figli," that precedes his famous aria "Cari figli" in Act 2 Sc. IX of the eponymous opera [III; IV], and the dialogues of Enrico and Idalide, "Sei paga alfin" / Che angustia è questa!" (Act 1 Sc. IX), and Palmoro, Idalide, and Ataliba, "Ah purtroppo il conosco" (Act 2 Sc. XIII) in Idalide [V; VI]. It becomes clear that Sarti unequivocally tends to entrust such moments of catharsis to declamation, whereas vocal pieces - arias and ensembles that enclose such scenes, usually resolve the tension, amaz- 
ing in their virtuosic display and emotional exaltation. In so doing, Sarti once more exhibits his faithfulness to the classicistic reform movement in opera, resonating with similar famous scenes in operas by Gluck and Traetta, Jomelli, Bianchi, and Sacchini.

In his works for the Russian stage, Sarti proceeded to impress the audience with the dramatic power and sublime elevation of the recitative scenes. The main protagonists' dialogue, "Addio / Gia mi abbandoni?" from Armida e Rinaldo [VII], astonishes with music expressive of moral dilemmas, the bitterness of Rinaldo's choice between love and civic obligation. A similar intensity of moral elevation is further reached in Rinaldo and Ubaldo's debate "E abborisce l'aiuto!" (Act 1 Sc. IV and VI).

Sarti's reputation as a master of elevated dramatic declamation was reinforced in the famous Greek Scene from Nachal'noe upravlenie Olega - the historical play on a text by no less than Catherine the Great, sensationally premiered on 22 September, 1790. [VIII] Sarti's music for the final act accompanied a meta-theater with the performance of a big scene from Euripides' Alcestis (verses 568-604 in the Russian paraphrase), in which he endeavors to imitate ancient Greek music. [VIII; 17-19].

The Greek Scene comprises two expanded sections: a dialogue styled as melodrama and the Ode to Apollo, set as a series of unison male choruses. The through-composed expanded scene in melodrama on a prose text is subdivided into three phases: the first portrays Heracles' arrival at Pherae, with the alternation of his spoken repliques and an accompanied unison chorus (“O! Druzi!" / "Zastanesh', Iraklii”, mm. 1-80); an unnotated dialogue between Heracles and Admetus with the latter's generous invitation to stay in his house ("Raduis'ia Zevsov syn!", mm. 81-130), accompanied by brief orchestral interjections; and the chorus' bewilderment regarding the Admetus' restraining mourning for Alcestis for the sake of noble hospitality ("Chto sie ty'delaesh', Admet'?", mm. 131-165). The orchestral accompaniment mirrors the emotional agitation and gravity of the text by using syncopated figures, dotted rhythms, and additional concitato devices. In his explanatory note Eclaircissement sur la musique composée pour Oleg, [IX, p. 361-4; X] where Sarti discussed in detail the musical arrangement of this scene, he admitted that the speech should be notated, but since he was composing it far from St. Petersburg, without being aware of the vocal capacities of the actors, he refrained from notating their speech and designed the dialogue as melodrama: ${ }^{2}$ "The Greek recitation had to have been notated, for it was accompanied by the lyre during the recitation of the players, and by the tibia during the singing of the Chorus. But I did not venture to notate the declamation of Hercules and Admetus, not knowing, firstly, the range of the voices of those who are to represent them. Secondly, what obstacle could such a novelty create for the interpreters, and how would they be able to carry out such a thing without the presence of the composer? [my emphasis. - B. B.-L.]" [IX, p. 361].

A closer observation of this scene indeed reveals Sarti's reluctance to incorporate spoken dialogue: while the outer sections present a coherent musical flow with lofty conversation of an individual with the choir (Heracles in the opening and Admetus in the closing subsections); the sophisticated debate between Heracles and Admetus on the identity of the deceased person sounds like a mechanical alternation of brief spoken phrases with monotonous one-bar orchestral repliques built of arpeggiated triads with their secondary dominants in the recitativo semplice style, but lacking its dramatic power. Some tension

2 The dramatic actors who performed Heracles and Admetus were Peter Plavilschikov and Emelian Shusherin. 
is accumulated at the point when Heracles approaches the solution of the Admetus puzzle - the subject of his mourning ("Uzhe umre", m. 100) - when harmonic progression is replaced with one chord (see ex. 2a-b).

As with Timoteo's monologue and cavatina discussed above, Sarti's classicistic ambition embraces instrumentation: the declamation alternates with interjections of harp and violin pizzicato in imitation of the lyre, and flute of the tibia. The composer explains the peculiarity of his instrumentation as follows: "I nevertheless accompanied this declamation by short interludes of the harp, intertwined with pizzicato on the violins, in order to represent, as closely as possible, the lyre of the ancients. $\langle\ldots\rangle$ In this way the actors will not have to worry about the music, assuming that they only declaim it in a loud voice, with the utmost nobility, as the Greeks did in order to impose their presence and be heard from far. It is to be hoped that the two actors will have beautiful voices in a low range, especially that of Hercules" [IX, p. 361-2].

Russian intellectuals prized the music of the Greek Scene for its moral loftiness and ideological significance. The statesman and littérateur Gavrila Derzhavin emphasized the pertinence of an ode, in conjunction with authentic or stylized instrumentation, as a representation of sublime and noble in tragedy: "In ancient times it was accompanied with a plain tune; it was sung with a lyre, psalter, gysli, harp, cetra, and in the newest times as well as with other instruments, strings more than anything else $\langle\ldots\rangle$. Nowhere can one sing powerful odes better or more elegantly $\langle\ldots\rangle$ to the immortal memory of the fatherland's heroes and to the glory of good sovereigns, as in an opera in the theatre. Catherine the Great knew this perfectly. We saw and heard the effect of the heroic musical presentation composed by her in wartime under the name Oleg" [20, p. 516-7, 602].

Sarti's use of melodrama versus unison chorus, apart from being circumstantial, and conditioned by his lack of confidence in setting Russian texts to music, ${ }^{3}$ could mirror his susceptibility to a novel and fashionable device that turned into a trend in Europe. During the 1760-70s, melodrama had already become a common component in works on tragic themes, though not necessarily linked to his urge for imitation of the stile recitativo. It had been used both as a technique in entire works, in different versions of Pygmalion by JeanJacques Rousseau, Anton Schweitzer, and Georg Anton Benda, or the latter's Medea and Ariadne auf Naxos, as well as an exceptional device in separate scenes in works by Christian Gottlob Neefe, Johann Friedrich Reichardt, Georg Joseph Vogler, Peter Winter, Christian Cannabich, Wolfgang Amadeus Mozart, and others [21, p.401-6; 22; 23, p.378-87; 24, p. 29-57]. Scenes in mélodrame became the mainstream in revolutionary France, in the opéra comique and its descendent the comédie héroïque, featuring in Les Mariages samnites (1768, revived 1776) and Pierre le grand (1790) by André Gretry; Jean-François Lesueur's Paul et Virginie (1794), Étienne Nicolas Méhul's Mélidore et Ephrosine (1794), and especially in opéra comique by Luigi Cherubini ${ }^{4}[23$, p. 371-83]. As an independent genre, mélodrame flourished in biblical dramas in the small theatres of the boulevards, such as Es-

\footnotetext{
${ }^{3}$ Although at this time Sarti had already gained significant experience in working with Russian texts, both original (as in the Russian oratorio "Da voskresnet Bog", 1785) and as contrafactum of his Latin-text compositions ("Tebe Boga hvalim", "Pomilyi mia, Bozhe" etc.).

${ }^{4}$ Cherubini used scenes in mélodrame in Lodoisca (1791): Act 1 Sc. V and final Combat; Elisa (1794): Act 2 Sc. V; Médée (1797): Act 2 Sc. VI; Les deux Journées (1800): Act 2 Sc. VIII, XII-XIII; Fanisca (1806) Act 1 Sc. V, Act 2 Sc. IX, and Act 3 Sc. XV. In addition, in 1806, Cherubini reported in his catalogue: a notation of "a chorus and melodrama composed at Paris for an opera which I did not complete" [27, p. 15]. All the translations, unless otherwise stated, are by the author.
} 


\section{EвPU⿴囗十}

MLC TIII AB A 1,2 , 3 :

$C X I 1$

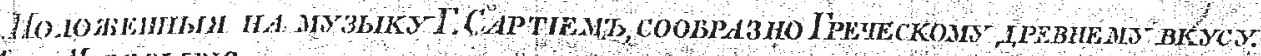
MovolMaș OLTZZO.

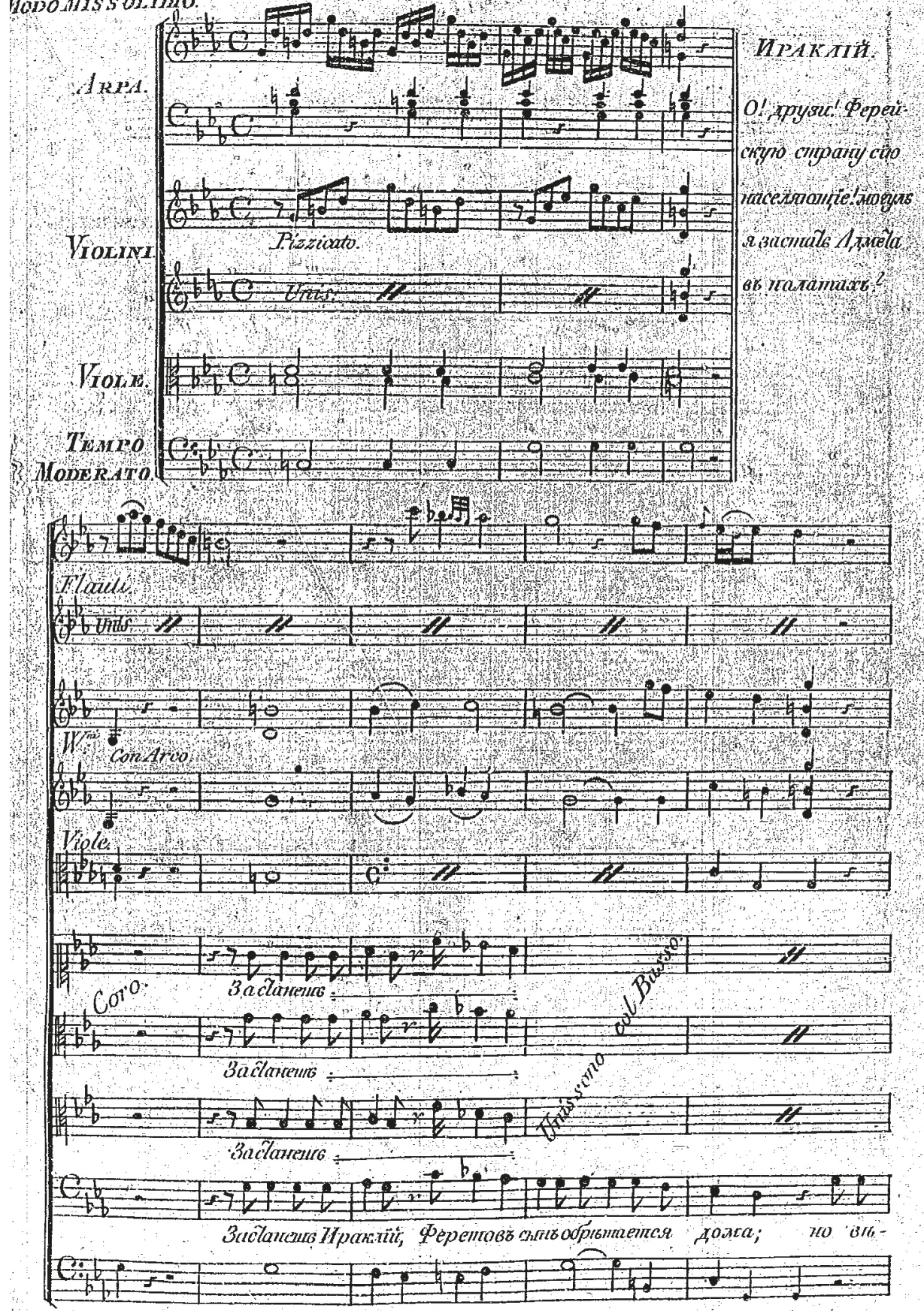

Example 2a: Giuseppe Sarti, Nachalnoe upravlenie Olega, Act 5 Scene 4, Melodrama, mm. 1-7. 


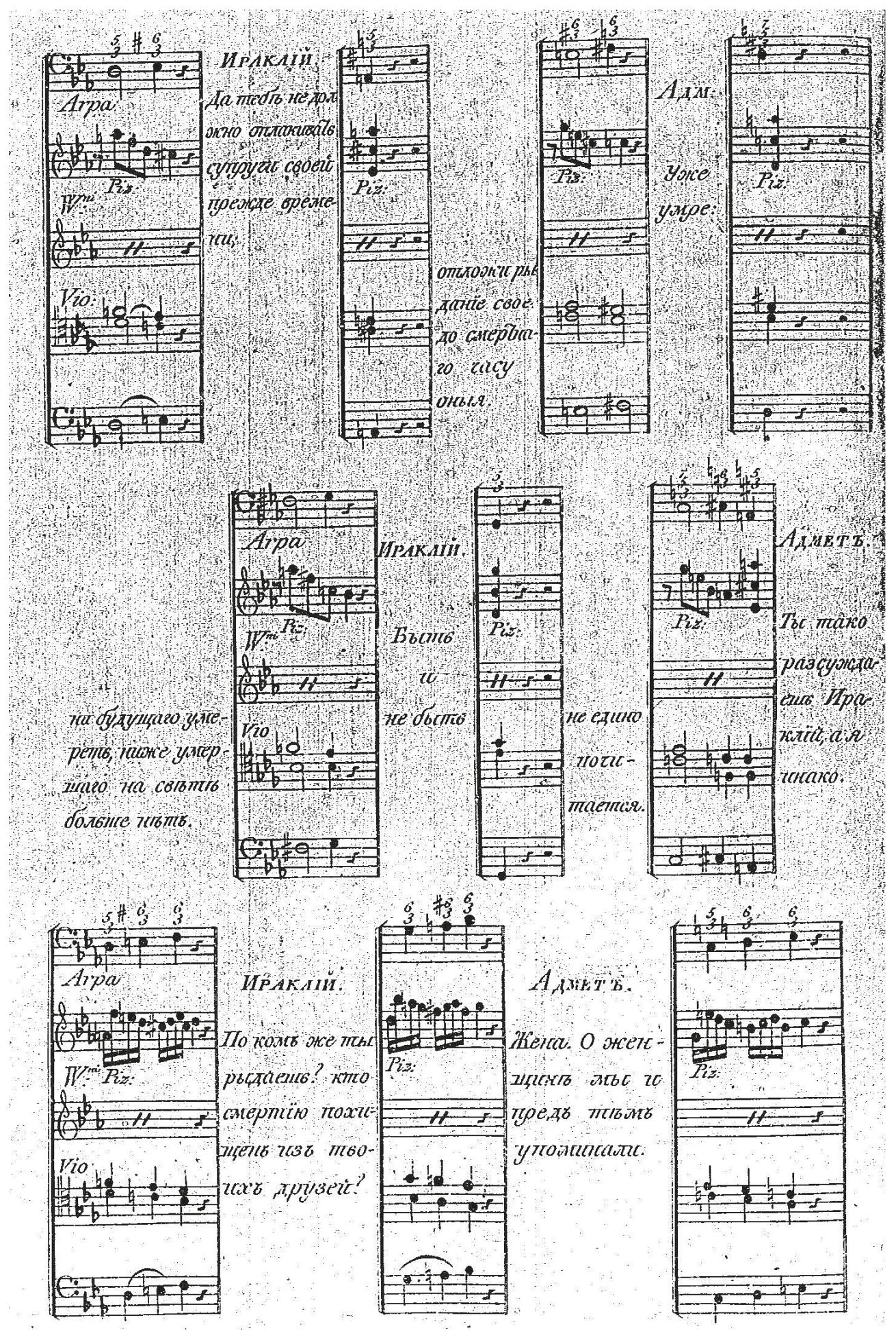

Example 2b: Giuseppe Sarti, Nachal'noe upravlenie Olega, Act 5 Scene 4, Melodrama, mm. 97-106. 
ther (Plancher Valcour, music by Leblanc, 1802); Le jugement de Salomon (Louis-Charles Caigniez / Quaisin, 1802); Le jugement de Daniel ou L'innocence de Suzanne (Vallée / Taix, 1805); Le triomphe de David (Caignez / Leblanc, 1805); Samson ou La destruction des Philistins (Romagnesi / Ribié, 1806); Pharaon ou Joseph en Egypte (text and music by Pierre Charles Joseph Lefranc, 1806), etc. [25; 26, p. 59-63]. In the biblical melodramas, this interest to connect the declamation with the choruses was also in large part inspired by the revival of late seventeenth-century classicistic dramas. Thus, Jean Racine, in the Preface to Esther (revived in Paris in 1805), wrote: "I realized that by working on the plan that had been given to me, I was executing in a way a design that had often passed into my mind, which was to bind, as in the ancient Greek tragedies, the choir and the song with the action, and to use for singing the praises of the true God that part of the chorus that the pagans used to sing the praises of their false deities [my emphasis. - B. B.-L.]" [XI].

Of Italian opera, melodrama (melologo) remained generally atypical, due to the traditional preference for vocal culture as the main vehicle for dramatic and emotional expression, and due to its strong conventions of a genre. At the same time, Italians working abroad in foreign cultures displayed their susceptibility to this new vogue. It is worth mentioning a melologo Werther by the Piemontese composer and violinist Gaetano Pugnani (1731-98), performed in German in Vienna (1796) [XII]. This monumental score adopts Goethe's epistolary novel Die Leiden des jungen Werthers (1774); it is constructed as an alternation of closed orchestral numbers with a narrator's enunciation of letters. Only in some episodes, when the letter describes balls and dancing, or Charlotte playing the piano, do music and text overlap.

Another bold example that could serve is Scene VI of Act 2 in Cherubini's Médée (1797), on a libretto by François-Benoît Hoffmann [28; 29, p. 129-31; XIII, p. 256-69]. Similar to Sarti's Greek scene, although on a much subtler level, it presents the sequence of a male unison nuptial chorus "Fils de Bacchus," followed by Médée's repliques in melodrama (replaced with recitative in the later version). It is introduced at the climactic point of the tragedy, while the solemn strains of the wedding procession underline Médée's painful observation of her beloved husband's marriage to Dircé [29, p. 131]. Such a combination of obbligato recitatives and melodrama in conjunction with unison male choir, characteristic orchestration, and pantomime, although being developed concurrently by French composers, could be considered Sarti's individual penchant, to which our composer did not hesitate to return in the wake of Oleg's triumphal performances.

Scene VII from Act 2 of Sarti's penultimate Italian opera - Andromeda, on a libretto by Ferdinando Moretti [XIV-XVI] - depicts the most thrilling moment of the drama. It displays the strenuous combat of Perseo with the sea monster, with the enchained Andromeda on a rock watching with bated breath, and a chorus of the people of Jaffa observing and commenting on the battle from the seashore. This tableaux vivant is a culmination of pantomime (with choreography by Charles Le Picq, decorations by Pietro Gonzaga), melodeclamation, and chorus: Andromeda's aspirations are declaimed to free verses, with brief phrases in declamation and recitative alternate with her measured singing with the chorus, followed in the next scene by the triumphal chorus of priests (see ex. 3).

Summarizing these examples, it becomes clear that Sarti's notion of the tragic was conceived as a firm link with classicist ethical and moral rigor. In his dramatic oeuvre Sarti preferred to convey the sublime atmosphere of tragedy through unmeasured text and declamation, whether notated or not, and not via cantilena and ciosec operauc 


\begin{tabular}{|c|c|}
\hline Andromeda & Perseo! Misera me! Perseo! Ei s'avanza \\
\hline & Sul lido estremo! Aimè! Chi lo soccorre? \\
\hline & Mentre cerca salvarmi a morte ei corre. \\
\hline & CORO. \\
\hline & Da' suoi dardi già ferita, \\
\hline & Verso lui la belva viene. \\
\hline Andromeda & Ah che vedo! chi l'aita? \\
\hline & CORO. \\
\hline & La sua lancia si spezzò. \\
\hline Andromeda & Onde mai sperare aiuto? \\
\hline & CORO. \\
\hline & Ma del mostro il ferro acuto \\
\hline & Nelle fauci penetrò. \\
\hline Andromeda & Finisca il viver mio. Vista si atroce \\
\hline & L'anima oppressa a sostener non vale \\
\hline & CORO. \\
\hline & Con la spade ei già l' assale. \\
\hline & Glie la immerse nella gola! \\
\hline Andromeda & Ah qual colpo! \\
\hline & CORO. \\
\hline & Il mostro freme, \\
\hline & Ha negli occhi il foco, e l' ira... \\
\hline & Si dibatte... cede... spira... \\
\hline & Ed i lumi già oscurò. \\
\hline Andromeda & Che miro! Oh Dei pietosi! \\
\hline & E non sogno? Ed è ver? Già d' ogn' intorn \\
\hline & Di quell' infame sangue il mare è tinto. \\
\hline
\end{tabular}

Example 3: Ferdinando Moretti, Andromeda. Dramma in due atti con balli analoghi. St. Petersburg: Imperial Publishing, 1798, p. 50.

forms. ${ }^{5}$ The location of these portions of declamation at the climactic points of the drama was carefully calculated. He succeeded in attaining great dramatic tension due to the dialogue structure and an alternation with choruses (in unison or in plain chordal texture), and illustrative elements in the orchestra. Often, Sarti's classicistic ambition in such scenes embraces instrumentation: arpeggio of harp or pizzicato of strings as an imitation of a lyre. Closed musical pieces - choruses, dances, or arias - that follow such a scene, sustain or resolve the tension.

How did Sarti transmit his vision of the tragic to his disciples and admirers in Russia? From its very beginning Russian national opera fixed its identity as a comedy based on everyday domestic plots, sentimental pastorals, or fairy subjects. Comic opera thus established a robust tradition on Russian soil, featuring dozens of original works and even more numerous arrangements and translations. It was represented by an impressive

${ }^{5}$ On musical units and their dramatic functions in late eighteenth-century opera seria see $[30 ; 31$, p. 448-50]. 
variety of literary subspecies, including the "drama with voices" Rozana i Lubim (Kerzelli / Nikolaev, 1788); the grotesque buffa Neschastie ot karety (Pashkevich / Kniazhnin, 1779); the folk vaudeville Mel'nik - koldun, obmanshchik i svat (Sokolovsky / Ablesimov, 1779); the satiric comedy Skupoi (Pashkevich / Kniazhnin, 1782); the "comedy with arias and dances" (comédie mêlée d'ariettes) Sokol (Le faucon, Bortniansky / Lafermière, 1786) and Amerikantsy (Fomin / Krylov, 1800); "igrishche nevznachai" ("an unintentional play") Jamshchiki na podstave (Fomin / L'vov, 1787), the political pamphlet Gore-bogatyr' Kosometovich on Catherine II's play with the music by Martín y Soler (1789), and many others. [32; 33; 34, vol. 2, p. 163-88; 35, p. 99-187; 36; 37, vol. 2, p.67-130]. All these comic operas lacked recitatives and retained spoken dialogue.

At the same time, tragedy in music did not settle down on Russian soil, despite bold precedents by Francesco Domenico Araja, who served the Russian crown during 1735-62. Apart from a dozen Italian serious operas composed by Araja in Russia, his Tsefal i Prokris on Alexander Sumarokov's text (based on Ovid's Metamorphoses, 1755) became the first opera in Russian - a somber tragedy of faithful love disrupted by the intervention of the gods, and lacking the traditional happy ending (il lieto fine) of Italian opera seria. Sumarokov's text, written in metric verses throughout, was set by Araja in the traditional operatic distinction between vocal numbers and recitatives. ${ }^{6}$ Three years later, the newly appointed music director of the Russian court Hermann Friedrich Raupakh presented the second tragic opera in Russian, Alkista (on Sumarokov's arrangement of Euripides) - which preceded Gluck's masterpiece by almost a decade and became a significant cultural event.

The foremost late-Settecento Italian musicians, during their tenures at the Russian court, presented new serious operas that became the chefs doeuvre of the genre: it suffices to mention Ifigenia in Tauride by Baldassare Galuppi (1768) with its civil pathos, or the emotionally and dramatically powerful Antigona by Tommaso Traetta (1772), both on librettos by Marco Coltellini. Vincenzo Manfredini, whose Russian career (tenure 1758-68 and 1798-99) was only moderately successful, staged three serious operas in Russia, Semiramide, L'Olimpiade, and Carlo Magno (during 1760-63). Domenico Cimarosa (1787-91), a genuine composer of sparkling opere buffe, was forced to entertain the Russian court with serious operas on Ferdinando Moretti's texts: La vergine del sole (1788) and La Cleopatra (1789), in which he did not succeed [33]. During this same time, native Russian composers produced significant opere serie for Italian theaters: Maksim Beresovskii's successful setting of the Metastasio's Demofonte (1773, Livorno); Dmitrii Bortnianskii's Creonte followed by Alcide for the Venetian Teatro S. Benedetto (1776 and 1778), and Quinto Fabio for Modena (1779); Rinaldo by Peter Skokov (libretto by Sernicola) was staged in 1788 in the Neapolitan Teatro San Carlo [38, p. 119-31; 39 p. 55-86; 40].

Derzhavin, the spokesman of Russian Enlightenment and neo-classical movement, considered opera the best and solely musical equivalent of the Greek tragedy. It is worth quoting a sizeable excerpt from his treatise "On lyrical poetry" that unequivocally shows this notion:

Opera $\langle\ldots\rangle$ in many respects is nothing else than an imitation of ancient Greek tragedy. $\langle\ldots\rangle$ regarding to its moral aim, what prevents raising it to that same level of dignity and respect that characterized the Greek Tragedy? <..> It is known that in Athens the theater was a political

${ }^{6}$ Araja, as later Sarti, did not read Russian; the text is written in Latin transliteration. Findeizen [37, p. 154-63] emphasized the national importance of this premiere since singers, actors, and musicians were native Russians. 
institution. With it Greece maintained for a long time the righteous feelings of its people, proving its advantage over the barbaric ones. It has been written and sufficiently said that honour is a passion of noble souls; that nothing else can give birth to heroes and govern their hearts than it. $\langle\ldots\rangle$ Nothing amazes the people's mind $\langle\ldots\rangle$ as these fascinating spectacles. This is the essence of the aréopage's politics and a true destination of the Opera $<\ldots>$.

Following the ancient custom, for the sake of its marvel, Opera - naturally, the tragic one - draws its content from pagan mythology and ancient and medieval history. Gods, heroes, knights, fairies, sorcerers and magicians are its protagonists $\langle\ldots\rangle$. An author of both operas and tragedies could arrange the same content, displaying famous deeds, complicated with contrasting passions, that end with amazing denouements of solemn or plaintive adventures. The Opera writer differs from the tragic [author] solely in that he valiently deviates from the natural track or even abandons it altogether, amazing the spectators with frequent changes, diversity, splendour and marvels, irrespectable of whether it is natural or unnatural, apparent or miraculous. In the tragic genre, the preferable [mood] is the touch of sublime, that reveals itself with the help of strong passions, and not just with words; that avoids sophistication of fable and action, chooses plainness, does not haste too much, knowing that this goes counter to the nature of singing, and more than all this avoids long and tiresome resolution, considering that this is a rational feature that is appropriate for Tragedy but not for Opera, where more feeling should be shown, in the course of which the speeches and deeds are expressed with brief and clear language. Songs or odes for choruses, when appropriate $\langle\ldots\rangle$, should be plain, strong, not pompous, and filled with vivid feeling. $\langle\ldots>$ A singer and composer will be able to borrow from him neither expression nor pleasure. The Opera writer should necessarily know their talents and adjust himself to them, or vice versa, in order to attain a harmony of all its components [20, p. 598-604].

Despite this detailed declaration of an urge for national appropriation of the serious opera, isolated sporadic attempts to create a grand mythological opera on a Russian text produced specimens, but failed to sustain a tradition.

It appears that Russian was first and foremost conceived as a literary language, not as a means to express a text musically. Tragedy thus for a long time remained solely a domain of a spoken drama. Apparently, an adjustment of the distinction between the blank and metric verses, essential for European operatic librettos, to the new principles of tonic-syllabic versification of the Russian literary language, proved difficult to achieve. Musically appropriate Russian speech-declamation in serious dramatic genres thus became a substantial challenge to be confronted and solved only in the wake of the Napoleonic epoch and the powerful national movement it evoked. Nevertheless, the territory of tragedy and serious drama did not remain entirely foreign to Russian theater, and found an outlet in the amalgamation of a ramified musical component that included overtures and orchestral entr'actes, choruses, folk songs, and ballet. ${ }^{7}$ Russian theater had accepted the European experience with mixed conceptions of word-sound-motion relations, albeit the musical and spoken levels remained unsynchronized. Maria Shcherbakova noticed the generic fluidity of integrating music with drama, defining the situation as a specific generic synthesis in each work [41, p. 13].

In what way did Sarti contribute to the musical appropriation of tragedy in Russia? Among his colleagues and compatriots, Sarti remained in Russia for the most extended period, serving two emperors (1784-86 and 1792-1801) and spending four years in voluntary exile in MaloRossia. Of his fellow compatriots, only the tenures of Araja and

\footnotetext{
7 Similar assertion has been made by Alexander Glumov in 1950 [21, p. 26].
} 
Catterino Cavos (1798-1840) proved longer, and their convergence with Russian national culture became equally strong.

Unlike other foreigners, Sarti was recognized as mainly a serious composer; he was "entrusted" to marry European classicism, with its emphasis on the representation of the sublime, lofty, and serious, with local music. Sarti's impact on Russian culture has been recognized mostly as a creator of a corpus of oratorios, cantatas, and hymns on Russian and Old Slavic texts, and panegyric music for choirs and orchestra, with unusual timbral effects, artillery (cannon shots), bells chime, and fireworks. In this field, he indeed greatly influenced Russian church and civil compositions. [34, vol. 2, p. 273-81; 37, p. 100-4; 42, vol. 2, p. 274-88; 43, p. 217-29]. At the same time, his removal from court and theater life significantly limited his activity as dramatic composer. Nevertheless, I shall attempt to further demonstrate the Sarti's crucial impact on the development of the tragic subject in Russian dramatic music.

Mikhail Ivanov-Boretskii emphasized Sarti's pivotal contribution to Russian music as a highly esteemed pedagogue: "He not only composed music (including works for the Russian church) and performed his operas, which other Italians had been doing, but he raised the craft of performing in opera theater to a very high level and educated a number of talented students." [44, p.199]. Sarti trained most of the leading native Russian and Ukrainian composers of the period, and they clearly followed the patterns inculcated in them by the celebrated mentor. Some of these composers, such as Daniil Kashin (17691841), Artemii Vedel' (1767-1808), and Peter Turchaninov (1779-1856), were trained by Sarti on an institutional basis, during his service as a Director of the Music Academy in Kremenchug (presently Ukraine) in 1787-91 [45]. The affiliation of Stepan Davydov (1777-1825) with Sarti became most intimate: he lived in his teacher's house as a pensioner for six years, in 1795-1801, during which he was systematically trained and preached to by the aged master). ${ }^{8}$ Some others, without being Sarti's formal students, were close to him and took part in his musical activities: this was the case with Osip Kozlovskii (1757-1831), who served as an officer in Potemkin's army in Bessarabia during the Second Russo-Turkish War, but actually replaced Sarti as Potemkin's music director in 1790-91. [47, p. 432-3] Stepan Degtiarev (1766-1813)'s connection with Sarti is most obscure: in 1791, when Sarti was seeking employment with Count Nikolai Sheremetev in Moscow, Degtiarev was, albeit young, already a proved professional: remaining Sheremetev's serf musician, he was in charge of all the intense and multifarious musical activities, including conducting and directing performances of his serf theaters in Kuskovo and later Ostankino, private and public concerts where the Sheremetev orchestra and his Russian Horn band took part, hosting all foreign guest musicians and actors, and composing. ${ }^{9}$ Nevertheless, the influence - whether intentional or intuitive - of Sarti's style on Degtiarev's compositions remains undisputable. Evstignei Fomin (1761-1800), without taking lessons from Sarti, became strongly affected by his art due to strong public resonance Sarti provided for his musical activity.

Although it proves hard to reconstruct Sarti's teaching method in its entirety, some valuable information can be drawn from his work with another famous student, Luigi

${ }^{8}$ Davydov's study under Sarti was mentioned as a special proof of the former's stature long after Sarti's departure from Russia and his death [46, p. 15; 4, vol. 1, p. 288-90].

9 Assumptions by earlier scholars that during this period Degtiarev accompanied Sarti in his ostensible trip to Italy proved to be merely hypothetical [48, p. 338; 49, p. 128-9; 50, p. 155]. 
Cherubini, during 1778-82 in Florence, Bologna, and Milan [27, p. 1-2; 29, p. 22-4]. A brief excerpt found among Cherubini's manuscripts in Bibliothèque nationale de France, Paris, seems to represent a summary of certain principles of setting verses in dramatic recitative. It appears to be a draft of Sarti's unfinished pedagogical treatise Melopoea. ${ }^{10}$ This concise note is witness to the utmost significance Sarti assigned to the verisimilitude and dramatic potency of musically expressed speech: "The cantilena of the recitative must not be either too grave or too high; but it must imitate the inflection of speech, except in the cases where the sentiment of the discourse requires a more meaningful expression in the melody" [cit. after:23, p.331; 51, p.30-1]. His statement that "music must imitate the inflection of speech" anticipates the aesthetic credo of mid-nineteenth-century Russian national composers, resonating with the famous claim by Alexander Dargomyzhskii, "I want the musical sound to express the text directly, I want truth!" [53, p.57-8] (the letter to L.I. Belenitsina, December 9, 1857), and is a prediction of Dargomyzhskii and Musorgskii's pioneering efforts in the realistic formation of melodic recitative with a balance between the lyric and the naturalistic.

Sarti's experience with declamation and various styles of musically expressed speech found its continuation in various musical-dramatic subgenres, such as melodrama, ballet-pantomime, oratorio, and incidental music. Melodrama, although occupying quite brief local span of a couple of decades, became an important lieu for the integration of music with drama, perceptively mirroring the general process in the developments of both arts. On the one hand, its proximity to conventions and devices of opera positioned it as a musical-dramatic incarnation of the lofty ideals of classicistic tragedy. On the other, melodrama benefited from the flexibility of the combination of musical and dramatic elements. Fruitful for that stage of Russian national theater, scenographic principles of melodrama strengthened the pictorial qualities of music, turning them into the main conduits of dramatic content. Furthermore, the text of melodrama was free from the distinction between the blank verse (versi sciolti) and metric verse (versi lirici) that was strictly regulated in operatic libretti. All the text in spoken tragedies was written in metric verses, allowing the flexible combination of various styles of enunciation: from speech and declamation on a fixed pitch level to emotional prosody and even arioso-like segments.

The first melodrama composed in Russia in the native language was Orfei on Iakov Kniazhnin's text, by the Bolognese composer Federico Torelli (1781, music lost). Evstignei Fomin, ten years later (1791-92), presented a new setting [XVII; XVIII; 41, p. 43-6; 52]. In the wake of Sarti's Oleg, the Kniazhnin-Fomin Orfei became the aesthetic experiment for reviving ancient tragedy, amplified by the faithfulness to the myth, in which Euridice dies in the end and Orfeo is torn apart by furies. It has been generally agreed that since Fomin tragic pathos was recognized in Russian music.

Kniazhnin's poetic design of the text approximates an operatic libretto; it is based on the technique of speaking to different addressees, thus enabling sufficient scope for interrupting the dramatic action with static points of emotional reflection. Unlike many well-known Italian eponymous operas, the Kniazhnin's text conveys the climactic moment of the tragedy, showing the serpent biting Euridice, with Orfeo observing from the side. An additional peculiarity of the poetic source was that the dramatist gave precise hints at musical numbers to interrupt the spoken text, evoking an alternation and flexible

${ }^{10}$ Sarti mentions this in his brief letter to Cherubini of 6 October, 1801. Berlin: Staatsbibliothek zu Berlin Preussischer Kulturbesitz $(D-B s b)$. 
combination of melodramatic components and proper to opera elements: Fomin adapted the German model of melodrama, already successfully implemented by Sarti in Oleg, with a through-composed design: the text either precedes or follows the music, or is synchronized with it. The orchestral score boasts the typical vocabulary of melodrama, musically depicting the underworld with its paraphernalia, serpent's sting, Euridice's agonizing, and Orfeo's mourning and desperation via conventional rhetorical figures and topoi. Concurrently, musical numbers, such as Orfeo's "wordless arias," evoked by Kniazhnin's remark in the text "Orfei sings and accompanies himself on the lyre," with his voice personified by clarinet solo, supported with the pizzicato of strings (nos. 28 and 38 in the score); three bass choruses by invisible divine messengers ("Imej nadezhdu nesomnenno," "Pluton ustavy smerti razrushaet," and "Eshche tvoi chas," nos. 20,36, and 44), the overture, and the dance of furies (no. 55), are closed orchestral pieces. Fomin's operatic approach is further reinforced by the fact that Orfeo's repliques "K prekrasnoi solnechnoi strane" and "Prinudia zhit', zastaviti stradat"' (nos. 41 and 47) are both designated and designed as accompanied recitatives, although the declamation remained unrhythmicized. A chanting monophonic scansion of the unnamed basses, which emphasizes a strictly rhythmic text, is accompanied with the grave and somber sound of the Russian horn band - this bold detail of orchestration points unequivocally to the underworld scene from Sarti's Castore e Polluce (Act 4 Scenes I-II), with its unprecedented use of the Russian horns in an operatic score $^{11}$ [XIX; XX; 37, p. 55-67; 54, p. 33-41; 55, p. 130-42; 56]. An alternation of the hero's speech with harp arpeggio and monophonic chorus strengthens even more the resemblance with Sarti's works. The role of Orfeo was performed by the outstanding dramatic actors Ivan Dmitrevskii (in St. Petersburg) and Peter Plavilshchikov (in 1795 in Moscow), who earlier had impressed the audience with their rendition of main roles in Oleg, thus adopting the elevated style of the enunciation of the spoken text (see ex. 4).

Despite the truly stunning success of Fomin's neo-classical experiment, after the two additional fully-fledged melodramas on Alexander Kniazhnin's texts, Andromeda i Persei and Tsirceia i Uliss (1802) with music by Alexei Titov ${ }^{12}$ and choreography by Charles Le Picq, the yet to be established tradition of Russian melodrama as an independent work came to a halt. It seems that this fact as well eloquently supports Sarti's notion to employ melodrama as a separate scene or even a brief episode embedded in an opera or literary play. Such a scene was for the first time incorporated in the Russian opera Lesta, Dneprovskaia rusalka by Stepan Davydov, whose successful career was enhanced by Sarti's close patronage. ${ }^{13}$ Lesta (St. Petersburg: Kamenny, 1805) was defined as "comique opera in 3 acts, with choruses, ballets, magic, and transformations"; it is the third in a sequence of arrangements of the Austrian Singspiel Das Donauweibchen (Ferdinand Kauer / Karl Friedrich Hensler), translated by Nikolai Krasno-

${ }^{11}$ In early September, Fomin had already returned from his stay in Bologna, and attended the Hermitage performance of Castore e Polluce on September 23, 1786.

12 Apart from these melodramas, Titov's music for the dramas Sud Tsaria Solomona (1803), Amur sudia (1805), Polixena (1809), Emmerik Tekeli (1812), Prazdnik Mogola (1823); and his comic operas gained considerable popularity [57, vol. 4, p. 139-44].

13 Stepan Davydov began to study with Sarti around May 1795, when he graduated from the court chapel. By 1800 he held the position of music director of the Theatrical School. Apart from incidental music, he collaborated with Ivan Val'berkh on ballets, and he composed many sacred concertos, the full four-part liturgy of Iohann Zlatoust [John Chrysostom]; monumental choruses for Derzhavin's tragedy Irod i Mariamna (1806); Gruzintsev's Electra i Oreste (1809), etc. [46; 57, vol. 4, p. 145-67]. 

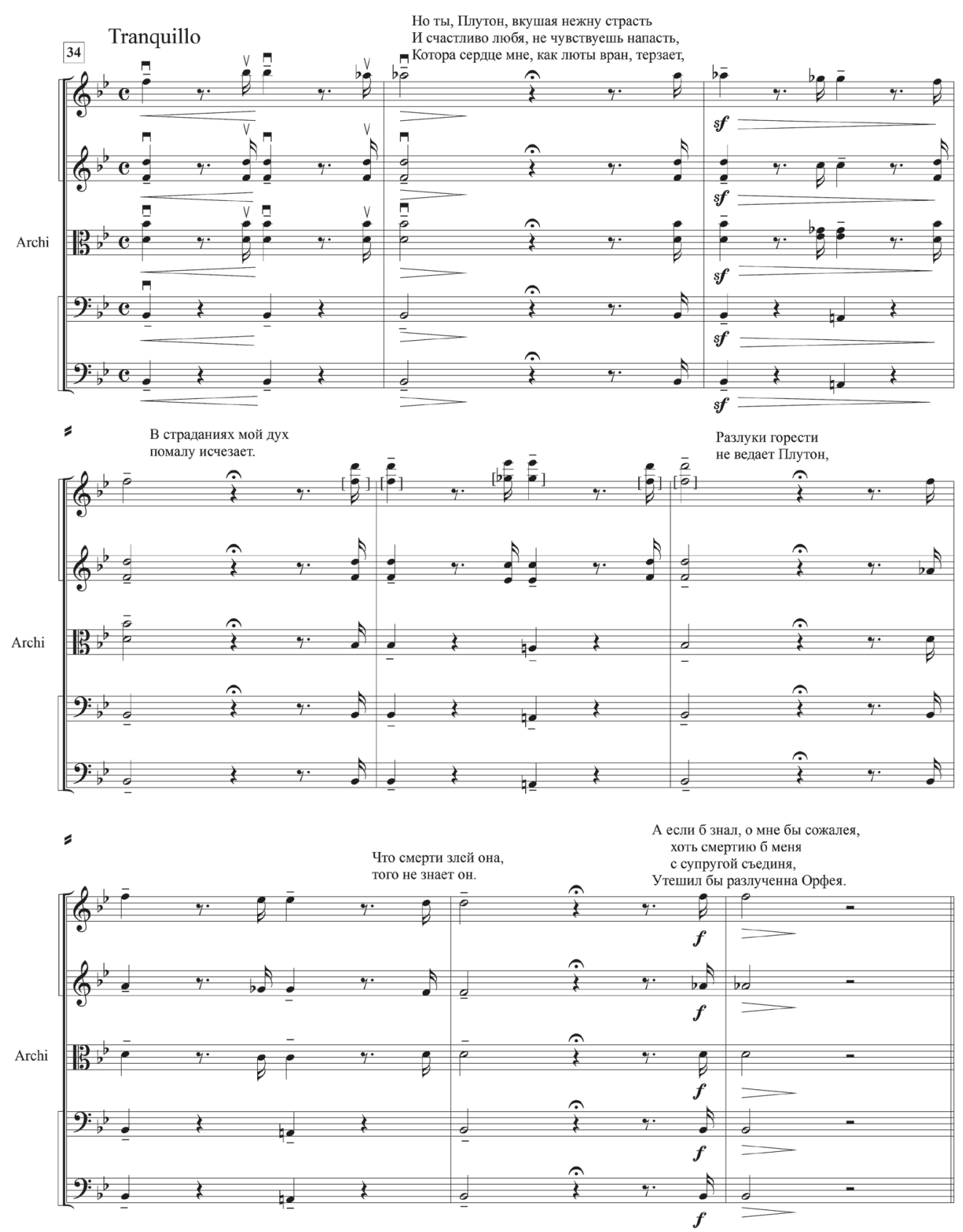

Example 4: Evstignei Fomin, Orfei.

pol'skii ${ }^{14}$ [XXI; XXII]. A compound scene in Act 2, where Lesta tells the water maidens the story of her tragic fate, has a through-composed structure, commencing with an orches-

14 1: Das Donauweibchen (1803) Kauer / Hensler, with additional music numbers by Davydov; 2: Die Nymphe der Donau (1804), with additional music numbers by Catterino Cavos; 3: Lesta, Dneprovskaia rusalka (1805), and Rusalka (1807), with music solely by Davydov. 


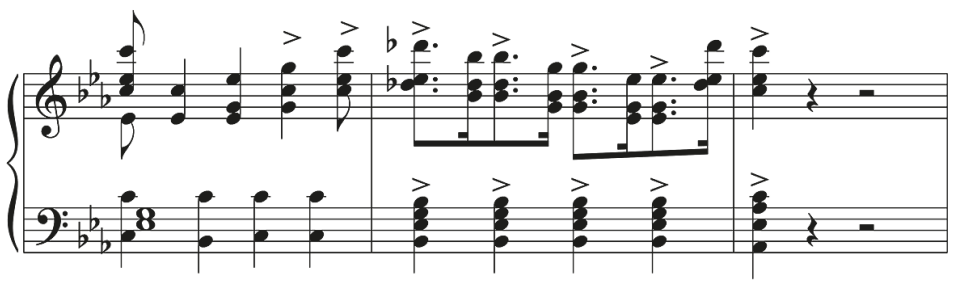

Л е с т а. Любезные сестры! Меня очень беспокоит что Видостан недоволен своею участью.

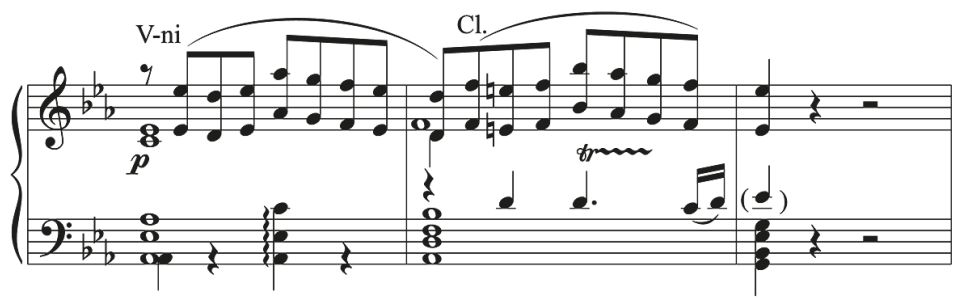

Скука и раскаяние терзают сердце его, и он старается избегать супруги своей.
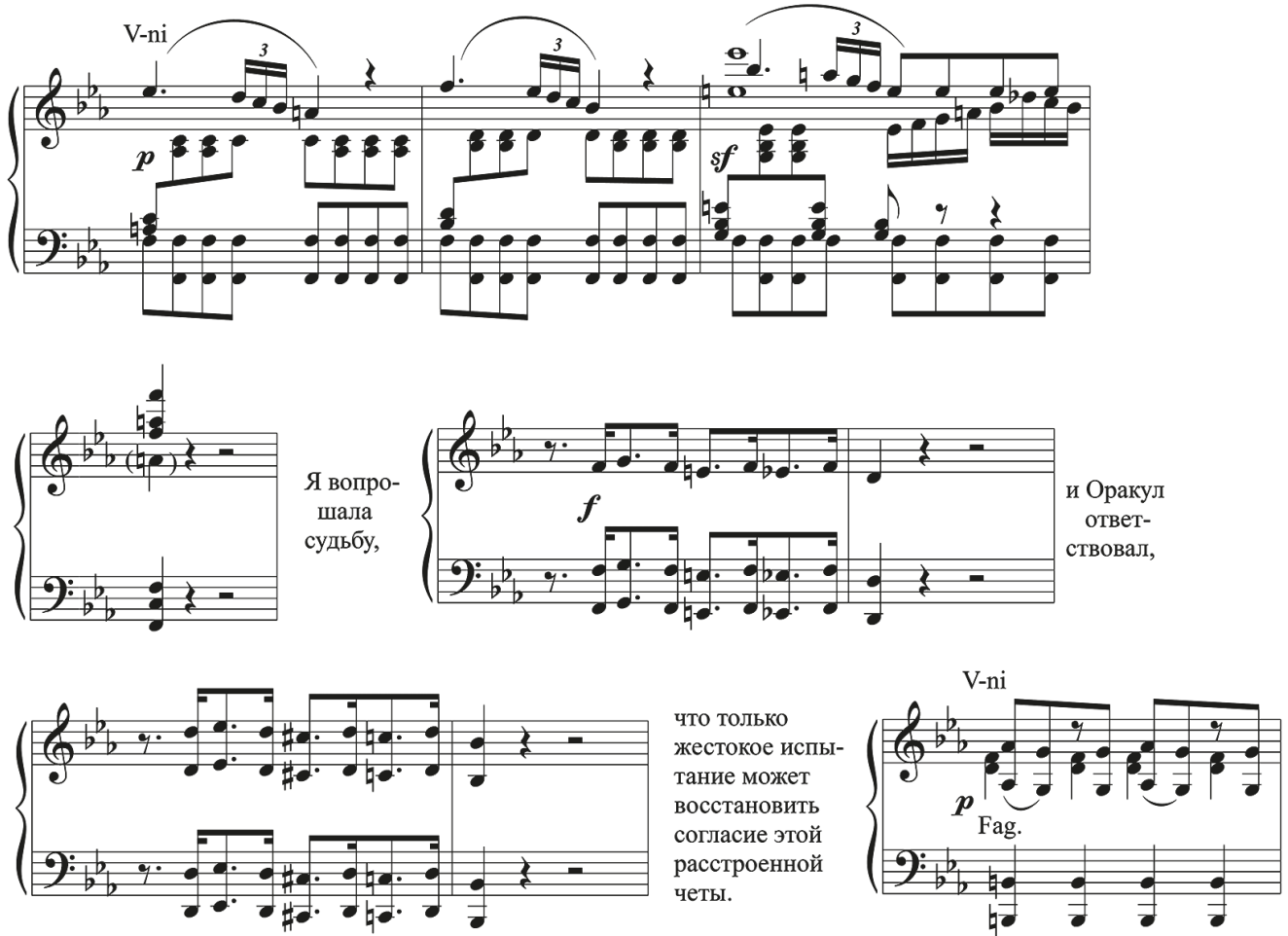

Example 5: Stepan Davydov, Lesta, Dneprovskaia rusalka, Act 2, Scene 1.

tral introduction that depicts a vibrating moon landscape. It leads to Lesta's agitated accompanied recitative alternating with the water maidens' chorus, trying to calm her down. Then follows the melodrama section: Lesta's unaccompanied declamation, which sounds quite tedious, alternates with closed musical units, enchanting in their orchestral splendor and bright timbral effects in a natural soundscape (solos of horns, bassoons, clarinets, and English horn; wind duets, mysterious arpeggio of harps and glass harmonica). ${ }^{15}$ The scene

15 In the finale of Act 3, Davydov uses timballi (pitched antique cymbals) with their high, silver, mysterious sound - a rare instrument frequently used by Sarti, and later in late-nineteenth century French music. 
is encompassed by a lavishly orchestrated instrumental piece: at Lesta's order darkness turns into dawn (see ex. 5).

Sarti's impact in attaining a powerful role for musical declamation in conveying serious subjects proves equally apparent in the heroic-patriotic oratorio Minin i Pozharskii, ili Osvobozhdenie Moskvy (1811) by Stepan Degtiarev, on a text by Nikolai Gorchakov [XXIII; 48; 58]. Unlike the traditional European-style oratorio (and lacking any generic precedent in Russian music), this score abounds in recitative sections displaying various styles of musical declamation. Gorchakov's text, metric throughout, while chiefly dramatic, does contain narrative and meditative portions. Atypically for an oratorio, it lacks the part of a narrator, since Russian audiences were very well acquainted with the events from relatively recent national history. At the same time, the dramatic parts contain many protracted recitative sections: the declamation alternates with brief orchestral motives (sometimes punctuated by one detached chord); emotional speech usually sounds over a background of sustained chords by winds. For moments of dramatic importance or for passages in which extra text expression is required, Degtiarev introduces characteristic melodic motives or distinct rhythmic patterns. Recitatives by Palitzin, "Gotov'tes' grazhdane" (Act 1), Prince Pozharskii’s "Chto vizhu ia?", "Suny otechestva", and especially "Gotov'tes' voiny" and "Spodviznikov moikh" (Act 2), and Minin's "Velikii podvig sovershilsia" (Act 3) eloquently illustrate the variety and expression of recitatives that point to Sarti's dramatic style as Degtiarev's source of inspiration. This resemblance becomes even more obvious due to a contrast between the hero's musical speech and the unison choruses by the Russian people "Dadim sebia kak Rossam" or "Emy prilichna slava" (Act 1). Sarti's formidable presence is supported particularly by the instrumentation: a Russian horn band is employed in six numbers, which enhances the solemnity of the music, including the duet of tenors and basses in Act 1 "Velik i vsemogushch Tvorets", and the trio "Iavi, Vsevyshnii, Pomoshch'!" of Minin, Pozharskii, and Palitzin in Act 2. Gorchakov's evaluation of the music for his text unequivocally points to the Degtiarev's dependence on Sarti's style: "After Bortnianskii, Degtiarev, pupil of the famous Sarti, occupies the first place among the ranks of the best composers of choral music. In his compositions is found an especially refined taste, developed according to the rules of the classical Italian composers: Pergolesi, Spontini, Cherubini, Leo, and so forth" [59, p. 203-4].

Paradoxically, portions of melodrama and musical declamation penetrated even works designated as ballets. ${ }^{16}$ Such ballets normally followed the performance of spoken dramas or operas as separate one-act works, or were inserted between the acts of the main play, elaborating on its subject and plot (balli analoghi). This situation instigated the strengthening of the dramatic conception of dance and pantomime that developed tools and devices for conveying serious dramatic ideas and plots and expressing strong human emotions. ${ }^{17}$

${ }^{16}$ From the 1760s, the Russian court became the center of activity of the foremost European choreographers, Gasparo Angiolini (during 1766-72), Giuseppe Canziani (1779-83 and 1784-92), Francesco Rosetti, Jean-Georges Noverre's disciple Charles Le Picq (1790-99), the first native Russian choreographer Ivan Val'berkh (1803-1819), and a series of brilliant French choreographers and dancers in the nineteenth century. [35, p. 199-232; 60; 61]. Val'bergh alone staged 36 original ballets, 10 restagings of his predecessors' works, and 42 divertissements in operas and dramas. He claimed his ambition "to create a moral ballet" [61, p. 15-6, 19, 21]

17 Music for the ballets was composed in collaboration with the choreographer (Giovanni Paisiello, Carlo Canobbio, Vicente Martín y Soler, and Guillaume Alexis Paris built successful careers as composers of ballets), or was used to existing music by various composers, or sometimes newly composed by the choreographer himself. 
In autonomous ballet performances, dance and pantomime - the main conveyers of dramatic action - were combined with music and spoken declamation, including melodrama. Thus, the tragic ballet in five acts Didon abandonée by Martín y Soler (1792) contains three big choruses [XXIV]. In Le Jugement de Salomon, Ivan Val'berkh's arrangement of a three-act Parisian melodrama by Louis-Charles Caigniez (1803), text portions of the melodrama (in translation by Alexander Klushin) were declaimed with music by Alexei Titov. Additional Val'berkh spectacles combined dance and pantomime with solo and choral singing, such as the Song of Russian Warriors in Act 1 of his four-act ballet-pantomime Russkie v Germanii, ili sledstvie liubvi k Otechestvu (1813); or a long scene in Act 2 with songs, choruses, and spoken dialogues in his Torzhestvo Rossii, ili Russkie $v$ Parizhe (1814), on music by Catterino Cavos [62, vol. 1, p. 59-62].

The pre-Napoleonic epoch and liberal period of Alexander I's rule became one of the most glittering pages in Russian history, marking the time of Russia's entry into world diplomacy, economics, military power, and cultural developments. An ebullient time of great expectations before the shock of the 1812 French invasion and the Patriotic War resulted in the great victory of the Russian people, it became as well a period of wide-ranging shifts of literary streams and ideological agendas: from the consistent position of Enlightenment ideology and classicism associated with the reign of Catherine the Great, to the sentimentalism that flourished during the brief rule of Paul I, to the powerful thriving of romanticism and the emerging aesthetics of realistic national drama [63, p. 129-55; 64-66].

On the eve of and during the war, dramatic theater moved into an avant-garde and proved most mobile in mirroring the growing patriotic feelings of Russian society. Rafail Zotov testified that "all branches of arts had then just one aim: love for the fatherland. On stage, [the public] did not want to see anything else but Russian, national [plays]. Literary success meant nothing! Everyone thought only of one subject, everyone lived with only one thought, breathed one desire - the greatness and glory of Russia. And never had history provided such events; never had the people so many reasons for enthusiasm; never was the people's enthusiasm for heroism developed with such a strength and in such a splendor, as in this great epoch" [67, p.23]. Historically oriented patriotism offered a new avenue to Russian authors. Repertory lists attest to a comfortable coexistence of plays based on the typical ancient or biblical subjects, old Slavic epics and history, showing heroic deeds and bold personages against the background of the national and civic environment. Mid-century classicistic dramas by Alexander Sumarokov and Iakov Kniazhnin hold their steady position in repertoire lists.

Kniazhnin's disciple Vladislav Ozerov (1769-1816) became the most esteemed Russian dramatist in the first decade of the 19th century. His plays gained tremendous popularity due to the atmosphere of sensibility with which he infused classicistic tragedy. Ozerov created a new tragic style, making literary expression more emotionally laden and significantly increasing its sentimental component. The latter circumstance provided perfect conditions for the intimate integration of music with tragedy, amplifying a heroic-patriotic pathos and embracing a rich emotional component. [41, p. 51-83;63] ${ }^{18}$.

In composing music for spoken tragedies, together with Davydov and Titov, the main figure became Osip Kozlovskii, who in 1799 was appointed inspector of music in the Im-

18 The same period saw a similar trend elsewhere in Europe; it is sufficient to recall Beethoven's music to Goethe's Egmont (1810), König Stephan, Op. 117, and Die Ruinen von Athen, Op. 113, by Kotzebue (1811). 
perial Theatres, and a year later became a director, with responsibility for the musical aspects of all productions ${ }^{19}$. Kozlovskii's adoption of tragic topoi in incidental music and apparently in his operas (which have not survived) was prepared in his solemn sacred compositions, mainly the Requiem Mass for the death of the last Polish king, Stanisław-August Poniatovskii (performed in St. Petersburg Catholic church on February 25, 1798). It absorbed many traits of Sarti's works in similar genres, namely their elevated monumentality, sharp dramatic contrasts between choral and solo movements, orchestral magnificence, and special timbral effects, including a Russian horn band (replaced with trombones in the second version), etc.

Kozlovskii's incidental music features six tragedies and contains the following numbers: Edip v Afinakh (Ozerov, overture and four choruses, 1804), Vladisan (Kniazhnin, 1786; staged with his music since 1805); Fingal (Ozerov, choruses of the bards, melodrama, pantomime, dances, pageants, military and battle scenes, 1805); Debora, ili Torzhestvo very (Shakhovskoi, 1810); Tzar' Edip (Gruzintsev, overture and two choruses, 1811); and Esther (Racine / Katenin's translation, 14 music numbers, 1816). The most ramified musical layer was created in Fingal, Debora, and Esther, embracing overtures, orchestral entreacts and choruses, ballets, melodramas, recitatives and arias, and demonstrating a tendency towards operatic treatment with its rich emotional expressive display.

Kozlovskii's music for Fingal - Ozerov's tragedy in three acts, based on James Macpherson's famous epic poem - is considered the best and most carefully elaborated, actually presenting his own musical-scenic rendition of the drama. Scene 2 of the play includes an epic song of the bard Ulline in threefold eight-line metric verses, in alternation with the chorus of the bards (two six-lines in the same eight-syllabic iambic meter), to 138 lines of the text. Kozlovskii's musical rendition of this scene, although relatively concise (160 measures of the score), truly astonishes with imaginative combination of various styles of text-music relations [XXV; XXVI].

After a brief eight-bar orchestral introduction, Ulline's declamation in melodrama, "Umolkni vse v strane podlunnoi" on four lines, alternates with square phrases of the orchestra that includes a harp part (Andante). The rest of his first verse depicts Fingal's battles, switching to an accompanied recitative (Allegro moderato) over a tempestuous orchestral background. The bards enter to "Udarili v medianyi shchit" with plain scansion in la battaglia style (Allegro vivace, triple time). Ulline's second verse, in Allegro furioso ("Vstaet Morvena vozhd' Fingal"), is recitativic throughout, with strong illustrative elements and timbral effects in the orchestra. The second choral verse, starting from the depiction of an arduous fight ("Mel'kaiut, seiutsia"), turns into the macabre scene of the deserted battlefield ("I stala vkrug ego ravnina," Andante lamentabile, with two solo cellos and strings con sordini). Ulline's last verse ("Padut, i neizbeg sud'bin") loosely combines melodrama over the tremolo of strings, with notated recitative. Bold contrasts of tempo and meter (although the poetic meter remains unchanged), orchestral effects, and a carefully planned tonal structure turn this scene in a true masterpiece (see ex. 6) [47, p. 451-3, 461].

It is considered that in the wake of Fingal's performances, the heroic idea was implemented in Russian music in a stable conjunction with an epic element - a discourse of an ancient bard supported by a stylized or actual accompaniment of a harp. Iurii Fortunatov

19 Tragedies by Kniazhnin were staged in the public theaters of both Russian capitals with music by Titov (Titovo miloserdie, 1790: "a tragedy in three acts, freely composed, with associated choruses and ballets"), Fomin (Yaropolk and Oleg, 1798), Bullant, and Kozlovskii. 


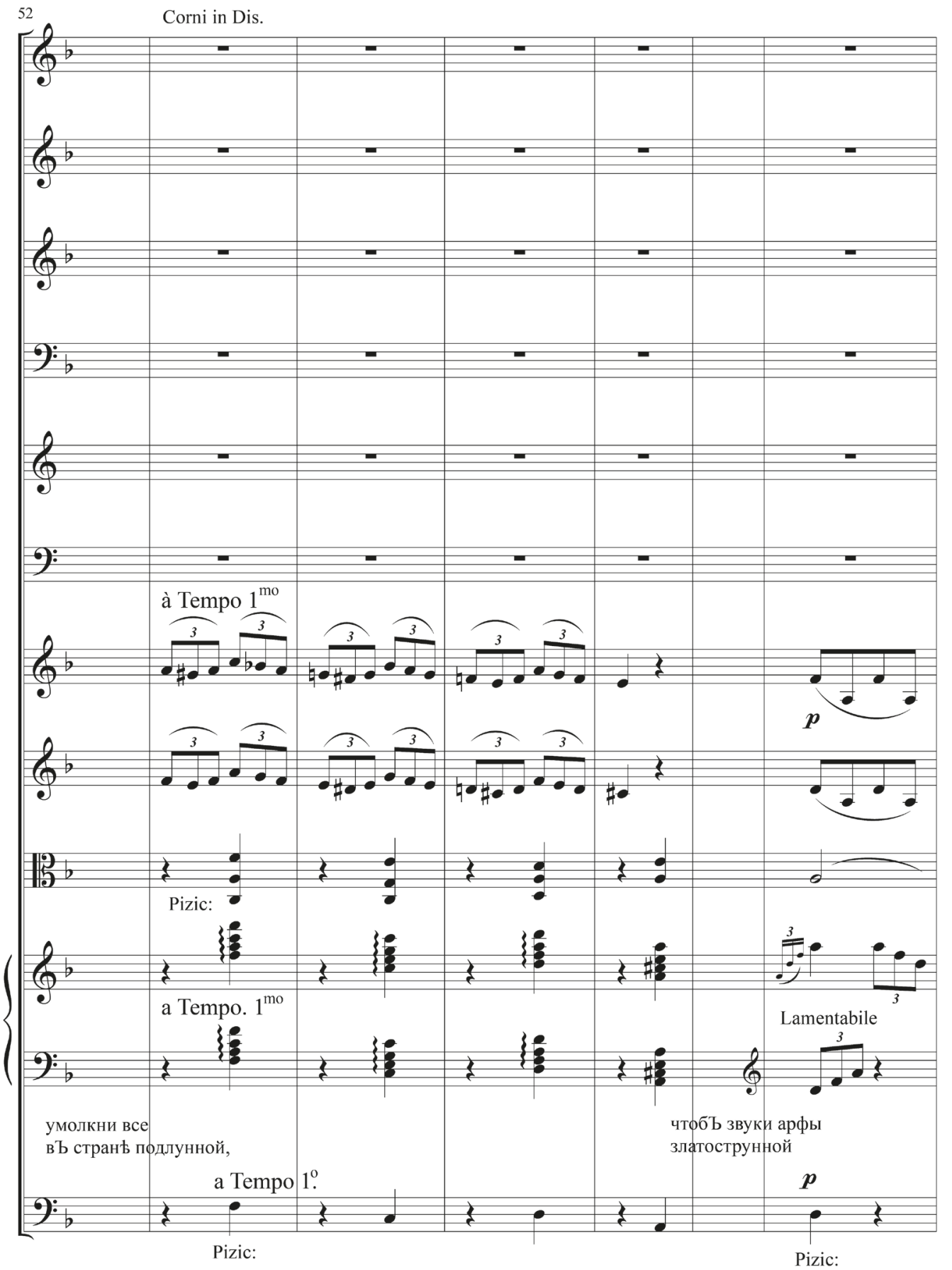

Example 6: Osip Kozlovskii, Fingal, 1808, Act 1 Scene I No. 2.

mentions the vocal cycle by Aliabiev "Baian's songs", the cantata "Three songs of a scald" by Verstovskii, and Baian's Song in his opera Vadim, and of course Glinka's Ruslan. Although melodrama from Fingal was enormously influential, its origins in the Timoteo monologues 
in Sarti's 1782' festa teatrale becomes rather transparent. Another Kozlovskii melodrama "Uslyshi greshnykh plach" from Debora - also astonishes with its combination of various styles of prosodic and musical declamation and eloquent rhetorical figures in the orchestra [XXVI]. His music for Esther creates strong dramatic contrasts between accompanied recitatives by an unnamed female personage and monophonic choruses of Israelite women in highly individual pieces, such as the Preghiera (Act 1, no. 5); Cantique "Blazhen narodov" (with elevated recitation supported by sustained chords of solo trumpet, horn, and trombone ad libitum and harp obbligato); the recitative "Bregisia, Tzar" and a four-part unison chorus "Sam sebia v zare proslavit" (Act 3, nos. 12-13) [XXVII].

The survey of scenes in melodrama in Russian music would be incomplete without mentioning Alexei Verstovskii's Askol'dova mogila, on a play by Mikhail Zagoskin; preceding Glinka's A Life for the Tzar by one year, it had a stunning success (Moscow: Bol'shoi, September 16, 1835) [XXVIII]. The dramatic conception and scenic history of Askoldova mogila proves quite complicated, resulting from its mixed generic identity - its subject from early Slavic history combines a tragic plot with strong folk and ordinary elements; singing and dances are interwoven with spoken dialogues and melodramas. Six scenes in melodrama include a folk-style scene in which a speech by a humble person alternates with two songs by Torop and an unison chorus of Kievan citizens, "Kak u duba kora" (Sc. II, no. 14). In the finale of the same act, another unison chorus and recitative (Sc. III, no. 24) by Vyshata complement orchestral music and melodrama by a serious unnamed person (Neizvestnyi). At the same time, a series of melodrama numbers with orchestrally supported pantomime impress with their mysterious atmosphere and tragic occurrence of events in the third act: a somber orchestral introduction in B-flat minor leads to the appearance of Rogneda's apparition, Vyshata's speech, the recitative of Rogneda's shadow (supported by a harp solo), and a sound of the invisible chorus (Sc. 4 no. 28). Tragic atmosphere is accumulated with two somber scenes in melodrama, preceding Stemide's death and contrasting with the chorus of pursuers (Sc. VI, nos. 36 and 38).

Sarti's decisive impact on the formation of Russian styles of musical declamation and a synthesis of drama and music proves undisputable. Naturally, complementary paths equally contributed to the appropriation of the tragic style in Russian music: these include the intense development of Russian drama, the art of outstanding Russian actors, such as Ivan Dmitrevskii, Peter Plavilshchikov, Emelian Shusherin, and the Sandunov and Yakovlev couples; the impressive innovative scenery by the famous stage designer Pietro Gonzago and his school; the growing trend of orchestral writing to elucidate the content and meaning of the text, and additional important developments. Nevertheless, Russian music remains immensely indebted to the Italian master for the domestication of tragedy that occupied the leading position in the imminent epoch of great historical, political, and social upheavals.

\section{References}

1. Odoevskii, Vladimir. Muzykal'no-literaturnoe nasledie. Edited by Vladimir Protopopov. Moscow: Muzgiz, 1956: 126-30. (In Russian)

2. Pfeiffer, Roland. "Giuseppe Sarti". In Die Musik in Geschichte und Gegenwart, $2^{\text {nd }}$ ed., edited by Ludwig Finscher, vol. 14: 977-87. Kassel; Stuttgart; New York, 2005. Accessed August 31, 2018. https:// mgg-online.com/article?id=mgg11372\&v=2.0\&rs=mgg 11372 . 
3. DiChiera, David, Marita McClymonds, and Caryl Clark. "Giuseppe Sarti." In Grove Music Online. Oxford University Press. Accessed August 31, 2018. http://www.oxfordmusiconline.com/grovemusic/ view/10.1093/gmo/9781561592630.001.0001/omo-9781561592630-e-0000024599.

4. Porfir'eva, Anna. “Giuseppe Sarti”. In Muzykal'nyi Peterburg, Entsiklopedicheskii slovar'. XVIII vek, edited by Anna Porfirieva, 79-93. St. Petersburg: Kompozitor, 2000, vol. 3. (In Russian)

5. Brover-Lubovsky, Bella, Christine Jeanneret, Nicolai E. Østenlund, and Roland Pfeiffer. "Sarti, Giuseppe Francesco Eligi." In Dizionario Biografico degli Italiani, vol. 90. Accessed August 31, 2018. http:// www.treccani.it/enciclopedia/giuseppe-francesco-eligi-sarti_\%28Dizionario-Biografico\%29/.

6. Winckelmann, Johann Joachim. Geschichte der Kunst des Alterthums. 5 vols. Dresden: Waltherischen Hof-Buchhandlung, 1764-1767.

7. Rosenblum, Robert. Transformations in Late Eighteenth-Century Art. Princeton: Princeton University Press, 1967.

8. Honour, Hugh. Neo-classicism. Style and Civilisation. Baltimore: Penguin Books, 1968.

9. Novotny, Fritz. Painting and Sculpture in Europe, 1780-1880. $2^{\text {nd }}$ ed. Harmondsworth: Penguin, 1980.

10. Brown, Bruce Alan. Gluck and the French Theater in Vienna. Oxford: Clarendon Press; New York: Oxford University Press, 1991.

11. Kirillina, Larissa. Reformatorskie opery Gliuka. Moscow: Klassika-XXI, 2006. (In Russian)

12. Heartz, Daniel. Mozart, Haydn, Early Beethoven (1781-1802). New York: Norton, 2009.

13. Lippmann, Friedrich. "Giuseppe Sarti: Giulio Sabino e Alessandro e Timoteo". In Musica e spettacolo a Parma nel settecento. Atti del Convegno di Studi indetto dall'Istituto di Musicologia, Parma, 18-20 ottobre 1979, edited by Rodobaldo Tibaldi, 105-16. Parma: Università di Parma, 1984.

14. Brover-Lubovsky, Bella. "Between Parma and St Petersburg: Giuseppe Sarti's Alessandro e Timoteo". Die Tonkunst 13, no. 1 (2013): 68-81.

15. Russo, Paolo. "Inebriati d'un nuovo genere di piaceri". Alessandro e Timoteo a Parma: metamorfosi della festa teatrale." In Serenata and festa teatrale in $18^{\text {th }}$ century Europe, edited by Iskrena Yordanova and Paologiovanni Maione, 431-56. Graz: Hollitzer Verlag, 2018.

16. Giust, Anna. "Il grand tour del granduca Pavel Petrovič Romanov: Andata e ritorno tra Russia ed Europa." Diciottesimo secolo, no. 2 (2017): 143-63.

17. Kirillina, Larissa. "In modo antico: the Alceste scene in The Early Reign of Oleg". Die Tonkunst 13, no. 1 (2013): 53-67.

18. Brover-Lubovsky, Bella. "The 'Greek Project' of Catherine the Great and Giuseppe Sarti." Journal of Musicological Research 32, no. 1 (2013): 28-62.

19. Frolowa-Walker, Marina. "Inventing Ancestry, Imagining Antiquity: Classical Greece in Russian Music." In Musical Receptions of Greek Antiquity: From the Romantic Era to Modernism, edited by Katerina Levidou, Katy Romanou, and George Vlastos, 2-34. Cambridge: Cambridge Scholars Publishing, 2016.

20. Derzhavin, Gavrila. "Razsuzhdenie o liricheskoi poe'zii”. In Sochineniia Derzhavina s ob"yasnitel'ny'mi primechaniiami, edited by Iakov Grot, 516-97. 9 vols. St. Petersburg: Imperatorskaia akademiia nauk, 1872, vol. 7. (In Russian)

21. Glumov, Alexander. Muzyka v Russkom dramaticheskom teatre. Moscow: Muzgiz, 1955. (In Russian)

22. Veen, Jan, van der. Le melodrama musical de Rousseau au Romantisme: Ses aspects historiques et stylistiques. La Haye: Martinus Nijhoff, 1955.

23. Selden, Margery Stomne. The French Operas of Luigi Cherubini. PhD diss. Yale University, 1951.

24. Charlton, David. "Storms, Sacrifices: The 'Melodrama Model' in Opera". In Charlton, David. French Opera 1730-1830: Meaning and Media, 1-61. London; New York: Roothledge, 2000.

25. Astbury, Katherine. "Music in Pixérécourt's Early Melodramas." In Melodramatic Voices: Understanding Music Drama, edited by Sarah Hibberd, 15-26. Aldershot: Ashgate, 2011.

26. Babić, Barbara. "Between Sacred and Prophane: French Biblical Melodrama in Vienna c. 1800." The Melodramatic Moment: Music and Theatrical Culture, 1790-1820, edited by Katherine Hambridge and Jonathan Hicks, 59-78. Chicago: University of Chicago Press, 2018.

27. Toulmon, Bottée, de, ed. Notice des manuscrits autographes de lamusique compose par feu M.-L.-C.-Z.-S. Cherubini. 1842. Reprint, London: H. Baron, 1967.

28. Russo, Paolo. "Visions of Medea: Musico-dramatic Transformations of a Myth". Cambridge Opera Journal 6, no. 2 (1994): 113-24.

29. Brover-Lubovsky, Bella. "Cherubini, Sarti, and the musica antica Movement in Italy." In Luigi Cherubini: Vielzitiert-bewundert-unbekannt, edited by Helen Geyer and Michael Pauser, 119-38. Sinzig: Studio-Verlag, 2016. 
30. McClymonds, Marita. "The Role of Innovation and Reform in the Florentine Opera Seria Repertory 1760 to1800." In Music Observed. Studies in Memory of William C. Holmes, edited by Colleen Reardon and Susan Parisi, 281-300. Warren: MI, 2004.

31. McClymonds, Marita. "The Venetian Role in the Transformation of Italian Opera Seria during the 1790s." In I vicini di Mozart, edited by Maria Teresa Muraro and David Bryant, 221-40. Florence: Olschki, 1989.

32. Berkov, Pavel, ed. Russkaia comediia i komicheskaia opera XVIII veka. Moscow; Leningrad: Iskusstvo, 1950. (In Russian)

33. Mooser, Robert Aloys. Répertoire alphabétique des Opéras, Intermezzos, Ballets, Cantates, Oratorios, joués en Russie Durant le XVIIIe siècle. Genève: Kundig, 1945.

34. Livanova, Tamara. Russkaia muzykal'naia kul'tura XVIII veka v ee sviaziakh s literaturoi, teatrom, $i$ bytom, 2 vols. Moscow: Muzgiz, 1952-53. (In Russian)

35. Gozenpud, Abram. Musykal'nyi teatr v Rossii ot istokov do Glinki. Leningrad: Muzgiz, 1959. (In Russian)

36. Giust, Anna. Cercando l’opera russa: La formazione di una coscienza nazionale nel repertorio operistico del Settecento. Milan: Amici della Scala-Feltrinelli, 2014.

37. Findeizen, Nikolai. History of Music in Russia from Antiquity to 1800, edited by Miloŝ Velimiroviĉ. 2 vols. Bloomington, 2010, vol. 2 .

38. Ritsareva, Marina. Maxim Berezovskii. Zhizn' i tvorchestvo kompozitora. St. Petersburg: Kompozitor, 2013. (In Russian).

39. Ritsareva, Marina. Dmitrii Bortnianskii. Zhizn' i tvorchestvo kompozitora. St. Petersburg: Kompozitor, 2015. (In Russian).

40. Malinina, Galina. “'Rinal'do' Skokova v Neapole - 'Armida' Sarti v Peterburge”. In Nasledie: Russkaia muzyka - mirovaia kul'tura XVIII-XIX vek, edited by Ekaterina Vlasova and Polina Veidman, 13-30. Moscow: Moscow State Conservatory, 2013, vol. 2. (In Russian)

41. Shcherbakova, Maria. Muzyka v Russkoi drame: 1756 - pervaia polovina XIX veka. St. Petersburg: UT, 1997. (In Russian)

42. Mooser, Robert Aloys. Annales de la musique et des musiciens en Russie au XVIIIe siècle. 3 vols. Genève: Mont Blanc, 1948-1951.

43. Ritsarev, Marina. Eighteenth-Century Russian Music. Farnham: Ashgate, 2006.

44. Ivanov-Boretskii, Mikhail. "Sarti v Rossii". In Muzykal'noe nasledstvo, edited by Mikhail IvanovBoretskii, 199-208. Moscow: Ogiz-Muzgiz, 1935, vol. 1. (In Russian)

45. Brover-Lubovsky, Bella. "Music for Cannons: Giuseppe Sarti in the Second Turkish War." In Music and War, edited by Étienne Jardin, 71-88. Turnhout: Brepols, 2016.

46. Fedorovskaia, Lidia. Kompozitor Stepan Davydov. Leningrad: Muzyka, 1977. (In Russian)

47. Fortunatov, Iurii. "Kompozitor Osip Antonovich Kozlovskii i ego orkesrovaia muzyka." In Osip Antonovich Kozlovskii: Orkestrovaia muzyka, edited by Evgenii Levashov, 417-63. Moscow: Kortran, 1997. (In Russian)

48. Hughes, Carol Bailey. "The Origin of 'The First Russian Patriotic Oratorio': Stepan Anikeevich Degtiarev's 'Minin i Pozharskii' (1811)." PhD diss. University of North Carolina at Chapel Hill, 1984.

49. Iazovitskaia, Elza. "Cantata i Oratoriia". In Ocherki po istorii Russkoi muziki 1790-1825, edited by Mikhail Druskin and Iurii Keldysh, 143-67. Leningrad: Muzgiz, 1956. (In Russian)

50. Elizarova, Nadezhda. Teatry Sheremetevykh. Moscow: Ostankinskii Dvoretz-muzei, 1944. (In Russian)

51. Pougin, Arthur. "Chérubini: sa vie, ses oeuvres, son rôle artistique." Le ménestrel, no. 48 (December 3, 1882): 29-31.

52. Schöning, Kateryna. "Das Melodram in Russland im ausgehenden 18. Jahrhundert: Giuseppe Sartis Euripides' Alkestis (1790) und Evstignej I. Fomins Orfeo (1791/92)." Musikwissenschaft Leipzig. Accessed August 31, 2018. https://musikwissenschaft-leipzig.com/2014/07/28/fomin/.

53. Dargomyzhskii, Alexander. Izbrannye pis'ma. Edited by Mikhail Pekelis. Moscow: Muzgiz, 1952. (In Russian)

54. Vertkov, Konstantin. Russkaia rogovaia muzyka. Leningrad; Moscow: Muzgiz 1948. (In Russian)

55. Levin, Semen. Dukhovye instrumenty v istorii muzykal'noi kultury. 2 vols. Leningrad: Muzyka, 1983, vol. 2. (In Russian)

56. Hughes, Carol Bailey. “Germs of Russian Musical Nationalism.” In Giuseppe Sarti: Musicista faentino. Atti del Convegno internazionale (Faenza, 25-27 novembre 1983), edited by Mario Baroni and Maria Gioia Tavoni, 149-58. Modena: Mucchi, 1986. 
57. Keldysh, Iurii, Olga Levashova, and Alexei Kandinskii, eds. Istoriia russkoy muzyki. 10 vols. Moscow: Muzyka, 1984-96. (In Russian)

58. Smolenskii, Stepan. "Oratoriia Step. Anik. Degtiareva”. Muzykal'naia starina no. 4 (1907): 68-90. (In Russian)

59. Gorchakov, Nikolai. "Ob ustavnom i partesnom tserkovnom penii v Rossii". Moskvitianin, no. 9 (1841): 191-207. (In Russian)

60. Dobrovol'skaia, Galina. “Ballet". In Muzykal'nyi Peterburg, Entsiklopedicheskii slovar'. XVIII vek, edited by Anna Porfir'eva, 79-116. St. Petersburg: Kompozitor, 2000, vol. 1. (In Russian)

61. Val'berkh, Ivan. Dnevniki. Perepiska. Scenarii. Iz arkhiva baletmeistera, edited by Iurii Slonimsky. Moscow; Leningrad: Iskusstvo, 1948. (In Russian)

62. Vsevolodskii-Gerngross, Vsevolod. Teatr v Rossii v epohy Otechestvennoi voiny. St. Petersburg: tip. Sirius, 1912. (In Russian)

63. Stennik, Iurii. Zhanr tragedii v Russkoi literature. Leningrad: Nauka, 1981. (In Russian)

64. Vsevolodskii-Gerngross, Vsevolod. I.A.Dmitrevskoi: Ocherk iz istorii russkogo teatra, edited by Dmitrii Petrov and Iakov Blokh. Berlin: Petropolis, 1923. (In Russian)

65. Vsevolodskii-Gerngross, Vsevolod. Istoriia russkogo dramaticheskogo teatra, 7 vols. Moscow: Iskusstvo, 1977, vol. 1. (In Russian)

66. Shuler, Catherine A. Theater and Identity in Imperial Russia. Iowa City: University of Iowa Press, 2009.

67. Zotov, Rafail. Teatral'nye vospominaniia. St. Petersburg: tip. Ia. Ionsona, 1859. (In Russian)

\section{Sources}

I. Sarti, Giuseppe. Alessandro e Timoteo. Dramma per musica, 1 act. Libretto C. della Torre di Rezzonico. Parma: Stamperia Reale, 1782.

II. Sarti, Giuseppe. Alessandro e Timoteo. Dramma per musica, 1 act. Naples: Conservatorio di Musica S Pietro a Majella $(I-N c)$, XXXI.3.16.

III. Sarti, Giuseppe. Giulio Sabino. Dramma per musica, 3 acts. Libretto [Pietro Giovannini]. Venice: Modesto Fenzo, 1781.

IV. Sarti, Giuseppe. Giulio Sabino. Dramma per musica, 3 acts. Score. Vienna: Artaria, ca. 1782. Naples: Conservatorio di Musica S Pietro a Majella $(I-N c)$, XXXI. 3.21

V. Sarti, Giuseppe. Idalide. Dramma eroico, 3 acts. Libretto Ferdinando Moretti. Milan: Giambattista Bianchi, 1783.

VI. Sarti, Giuseppe. Idalide. Dramma eroico. Score. Schwerin: Landesbibliothek Mecklenburg-Vorpommern Günter Uecker, Musikaliensammlung ( $D$-SWl), Mus. 4865.

VII. Sarti, Giuseppe. Armida e Rinaldo. Dramma per musica, 2 acts. Libretto Marco Coltellini. Score. Faenza: Biblioteca comunale $(I-F Z c)$, R. M. cart. 46

VIII. [Catherine II]. Nachal'noe upravlenie Olega $\langle\ldots\rangle$. Podrazhanie Shakespiry bez featral'nykh obyknovennykh pravil. Play and music by Carlo Canobbio, Vasilii Pashkevich, and Giuseppe Sarti. St. Petersburg: Typografia Gornago Uchilischa, 1791.

IX. Nachalnoe upravlenie Olega (The Early Reign of Oleg). Music by Carlo Canobbio, Vassili Pashkevich and Giuseppe Sarti for the Play by Catherine the Great. Edited by Bella Brover-Lubovsky. Recent Researches in the Music of the Classical Era 109. Middleton, WI: A-R Editions, 2018.

X. Sarti, Giuseppe. Eclaircissement sur la musique composée pour Oleg. Faenza: Biblioteca Comunale $(I-F Z c)$, R.M. cart. 38.

XI. Racine, Jean. Esther. Tragédie (1689) tirée de lécriture sainte <...>. Paris: Paul Fièvre, 1789.

XII. Pugnani, Gaetano. Werther: melologo in due parti da Goethe. Reconstructed by Alberto Basso; edited by Ruggero Maghini. Milan: Suvini Zerboni, 1985.

XIII. Cherubini, Luigi. Médée | Opéra en 3: Actes. Text François-Benoît Hoffman. Score. Paris: Jmbault, ca. 1800.

XIV. Sarti, Giuseppe. Andromeda. Dramma in due atti con balli analoghi. Libretto Ferdinando Moretti. St. Petersburg: Imperial Press, 1798.

XV. Sarti, Giuseppe. Andromeda. Act 1. Score. Faenza: Biblioteca Comunale (I-FZc), R. M. cart. 37.

XVI. Sarti, Giuseppe. Andromeda. Dramma in due atti con balli analoghi. St. Petersburg: Russian National Library (RUS-SPsC), Manuscript department. F. 891. No. 235-236.

XVII. Fomin, Evstignei. Orfei. Score, edited by B. Dobrokhotov. Moscow: Muzgiz, 1953.

XVIII. Kniazhnin, Iakov. Sobranie sochinenii. St. Petersburg: Tipografiia Gornago uchilishcha, 1787, vol. 2. 
XIX. Sarti, Giuseppe. Castore e Polluce. Dramma per musica in 5 acts. Libretto Ferdinando Moretti. St. Petersburg: Imperial Press, 1798.

XX. Sarti, Giuseppe. Castore e Polluce. Score: St. Petersburg: Rossiiskii Institut Istorii Iskusstv (RUSSpit) F. 2. Ed. 1. File 754.

XXI. Davydov, Stepan. Rusalka. Part 3. Piano-vocal score, nos. 1-17. St. Petersburg: P. Plavilshchikov, 1807.

XXII. Davydov, Stepan. Lesta, Dneprovskaya rusalka (excerpts). Istoriia Rysskoi muzyki v notnykh obraztsakh, edited by S. Ginzburg, 32-77. $2^{\text {nd }}$ ed. Moscow: Muzyka, 1969, vol. 2.

XXIII. Degtiarev, Stepan. Minin i Pozharskii ili Osvobozhdenie Moskvy. Score. Moscow: Deka-BC, 2006.

XXIV. Martín (y Soler), Vicente. Didon abandonée. Ballet tragique en cinq actes, De la composition de Mr. Le-Picq, représenté par le Théatre Impérial de St. Petersbourg en 1792, mis en musique par M. Martin, Maitre de Chapelle au service de Sa Majesté Impériale, et dédié à son excellence Mr. le Prince Yousoupoff. St. Petersburg: Breitkopf, 1792.

XXV. Ozerov, Vladislav. Fingal, tragédie en trois actes, traduite du Russe, en vers Français. par H. re J. Dalmas. Polnaia muzyka Khorov, Pantomim, Baletov, i Srazhenii Tragedii Fingala, Sochinennaia G. Kozlovskim. [Partton Complette des Choeurs, Balletset Combats de la Tragédie de Fingal, composée par Mr. Kozlowsky]. St. Petersburg: Dalmas, 1808.

XXVI. Kozlovskii, Osip. Orkestrovaia muzyka. Rossiiskii Institut Istorii Iskusstv, edited by Iurii Keldysh. Moscow: Cortran, 1997, pt. 11.

XXVII. Kozlovskii, Osip. Overture, entreacte and choruses for the tragedy Esther. St. Petersburg: Rossiiskii Institut Istorii Iskusstv (RUS-Spit), Manuscript department, F. 2-1 No. 33.

XXVIII. Verstovskii, Alexander. Askoldova mogila, Romanticheskaia opera v 6 kartinakh, edited by Maria Shcherbakova. Leningrad: Muzyka, 1983.

Author's information:

Bella Brover-Lubovsky — PhD, Professor; Bella.brover@mail.huji.ac.il 